\title{
An Encounter in Fieldwork: Subjectivity and Gendered Violence
}

Lydia Cole, Aberystwyth University

Moments when we fail to act weigh heavily on us. In such situations, we become witness to something but do not respond. Several days into my second fieldwork visit to Bosnia and Herzegovina $(\mathrm{BiH})$ I played a part in such a moment. Late in the afternoon, I was hurrying to meet a friend at a café on the banks of the river Miljacka in Sarajevo. Along the busy thoroughfare of Ferhadija toward the river, I noticed a man following a woman. From about ten metres away it became apparent that the woman was braced, her gaze locked firmly on the ground, while the man followed her. As they got closer, I heard the man repeating, Koji je tvoj broj telefona? ("What's your telephone number?") Standing still now, watching the moment unfold in front of me, I knew I should do something, yet I let them pass.

Months later, I sat in my basement office in Aberystwyth. As I pored through recordings of my interviews and hand-scrawled notebooks, I attempted to piece together my thoughts on witness and testimony for a chapter of my thesis. I had begun my fieldwork hoping to explore the production of gendered subjectivities in post-conflict justice processes. Indeed, many of the notes in front of me contained my reflections on conversations on these topics with various individuals working for international and domestic justice institutions, women's organisations and survivor associations. Yet, as I came to write, it was this chance encounter in the street and my response to it that stood out. It prompted reflection on how I was implicated in the very production I sought to explore.

My first reaction was to make sense of the encounter in my role as a researcher, interpreting my role as a witness to violence. Indeed, as Dauphinee writes on her field research immediately after the wars in $\mathrm{BiH}$, "seeking out the role of witness - is one implication of theorizing, which is in turn an implication of acting as a subject at large in the world, at large in the field, at large in the academy" $(2007,38)$. I took refuge in this role, asserting a duty to speak and bear witness, making sense of my encounter through literatures on testimony. In so doing, I produced the encounter and those in it as 
objects of study, a moment in which an act of gendered violence had occurred, which I could understand through recourse to feminist concepts like the continuum of violence. To use Kelly and Radford's (1990, 42, emphasis added) language, I saw that such encounters were often written off as moments where "nothing really happened." Throughout, however, I asserted my position as researcher-witness and the experience of harassment was produced as my object of study. Problematically, I remained a passive bystander. Though I spoke of bearing witness, I theorised at a distance.

This distancing has been explicitly challenged by Geertz $(1995,44)$, who suggests that the researcher cannot be understood to "penetrate another culture, as the masculinist image would have it. You put yourself in its way and it bodies forth and enmeshes you." My process of conceptualisation failed to account for the ways I was implicated in the encounter. I had failed to take myself seriously as a gendered body. What I realised is that, to the perpetrator in this encounter, my presence as a feminist researcher made no difference. Rather, it was my appearance as a female body that allowed the encounter to unfold with impunity. This erosion of difference brought forth an understanding of why this encounter was important. The experience made sense to me on a level I describe as visceral recognition: her head braced, face to the ground. The same ground to which I am rooted. I halt. My nerves tingling, mind racing in overdrive, the sensation unnerving since my body is so very still. Words rush up suddenly, stop and then silence. They pass. The moment passes.

\section{Notes on contributor}


Lydia is a PhD researcher in International Politics at Aberystwyth University. Her research focuses on gendered violence and post-conflict justice processes in Bosnia and Herzegovina, and draws on feminist theory, as well as conceptualisations of recognition and subjectivity.

\section{References}

Dauphinee, E. 2007. The Ethics of Researching War: Looking for Bosnia. Manchester: Manchester University Press.

Geertz, C. 1995. After the Fact: Two Countries, Four Decades, One Anthropologist. Cambridge: Harvard University Press.

Kelly, L. and J. Radford. 1990. "Nothing Really Happened: The Invalidation of Women's Experiences of Sexual Violence." Critical Social Policy 10 (30): 39-53. 